\title{
A Profound Study of Women's Pathetic Condition in Indian Society, the Selected Novels of Mulk RajAnand
}

\author{
Sulekha Varma, Raina Singh
}

\begin{abstract}
The subordinates are always suppressed, they can be known in terms of caste, class, gender, age. The current paper has attempted to analyze and uncover the most suppressed gender has been of the society in the selectednovels of Mulk Raj Anand. It would be an exploration of the concept or perception especially the women characters. The novel are Untouchable (1936), Coolie (1937) and The Road (1961).In these novels, he, indisputably, has established the reality of depreciating the women is the work of primordialpower of the apostolic people, who have finalized the future of them.
\end{abstract}

Keywords: Class, Caste, apostolic, Power, Subordinate

\section{INTRODUCTION}

The current paper, has tried to analyze the discovery of Mulk Raj Anand's subordinating the female character in his novels, so two novels are selected to give direction to the desired purpose, the novels are: Untouchable (1936), Coolie (1937). These two novels describe the suppressed image of the women. As they are taken as the weaker section of the society so they are the great sufferers. The dominating section or class of the society suppresses the women. As the women is supposed to dominate by the powerful section, in this regard caste plays a vital role, if the women are poor and low in caste so there are many reasons to suppress her. Caste is the powerful weapon to dominate the lower caste people, and if that is lady so condition becomes worst with her, it highly prevalent in Indian society.There are so many mean activities are active with these subordinate section while gendering and molestation to these women also play a prominent role to put them down to the lower strata and social scale of the society. Mulk Raj Anand is welcomed as the prominent critic of the colonial supremacy init varied forms. He also puts a weight in his fictional outturn. Anand has great concern about the subordinate women who are not having their identity and respect; they are just puppets in the hands of some powerful and dominating section of the society. They are taking advantage of caste-system, affluence as well as class-based domination.

Mulk Raj Anand after going through the book of Krishna Nehru Hutheesing, The Bride's Book of Beauty (1946), it is written in the collaboration of Anand. He passes the statement that the position of the women is very low and they are just taken as a doll,

Revised Manuscript Received on September 25, 2019.

Ms. SulekhaVarma, Assistant Professor, Graphic Era Hill University, Dehradun, India.

Ms. Raina Singh, Assistant Professor, Graphic Era Deemed to be University, Dehradun, India. who is not having any right to do anything of her choice, she has to follow others and this is the image, some dominating figures of the society has drawn for her. She is just for suppressing and dominating. Anand is expert to show the reality or the real image of the women in the society through his excellency of works. He tries to explore the dictatorship and autocracy of the male characters on the females. They are molested, insulted and oppressed by them.

There are so many theories and descriptions are given to the females like their identity, honor, position in society and regarding the future of society but the reality is very bitter, the reality is that they are humiliated, oppressed, and their identity has been snatched from them. The women are the silent sufferers; they are not able to do anything for they are not educated and self-dependent. So they tolerate the domination of the males, taking as their destiny. It highly stunning for Anand to believe that there is mute domination and suppression over the women, under the influence of apostolic heritage, instead of outraging the state level affairs. Most of the novels of Anand make an attempt to discover the traditional Hindu believes principals as well as preconception of men which has rooted the apostolic fervor in the society.

It is stated by Michael Foucault (1980) that the power is operated through the buildingof understanding. As well as building comprehension ofsexuality this put a control over the person. Actually men and women both are the pillars of the society and they are having varied social values, norms that depend on their position and level of power. The structures of male and female are different. There is great attention taken by Anand in his novels to show the suppressed female by the male domination. As males are having strong and powerful body structure in comparison to the female so they bull them by their robust personality.

\section{WOMEN ARE SUPPOSED A WEAKER SECTION OF SOCIETY, MEANT TO SUPPRESS}

The female characters are taken as the weaker sort of creature than males. The character of the novel Sohini in Untouchable, the creation of Anand suits the term as submissive, tranquil female. Actually she is an untouchable girl, who is very simple and disciplined. She waits patiently for high caste ladies to fetch water from the well. As it is the rule of the village that any low caste woman can't near the well to pollute it until the high caste ladies are drawing water.

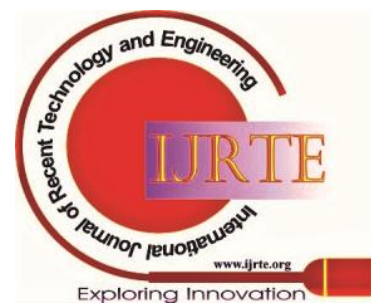


There is a priestKali Nath at the adjoining temple, is called Pundit by the villagers. He comes to Sohini to draw the water for her to give her that as reward for her patience waiting for water. It is norm of the society that a woman should follow all that, chalked out by the males, who belong to the higher strata of the caste in the society. As the characteristics like discipline, submissiveness to and patience all are the virtue of a decent and ideal lady.

The next novel of Anand is Coolie; Hari shows empathy and emotional approach to his wife, who is not so strong just because of her natural feebleness.In spite of being weak physically, she gives her cooperative hand to her husband in the factory, and provides same hours of service there. Even then she is treated as inferior to the males. Hari earns twenty rupees of his wages per month while giving same labor and time his wife gets five rupees of her wages per month. It is sheer partiality between the two genders. Anand has attempted to represents the women as intellectual, firm determined and highly fanciful even then they are not noticed just because of their biological feebleness. There is only one reason by which they are not taken as equal to males, the in-depth rooted perception of the apostolic people which is going on for years that the women are weak creature of the society and they can't compete the males. So they are not having any wish and aspiration to do according to themselves. On the whole, they can't live for themselves. It is an old perception that the females are very passionate by their nature, so they should be kept under the high administration and control of males. The female virginity is supposed to be very prominent and to keep it secure and safe is given extra emphasis in Indian society. As it is norm of the ancestors to keep the female as an object and personal property. They live within the strict rules and regulation throughout their life. They are cheated and befooled in the names of principles and rituals. The character of the novel in Untouchable, Bakha,and brother of Sohiniunderstands that his sister is pretty so takes her beauty responsible to stop her to do anything. Her blooming youth enchants and attracts all towards her. The males are very shrewdfor in the process of molesting the females, the find out the way to the worst activities remaining pious and blameless within their areas in the best possible manner. Kali Nath, the Pundit molestsSohiniphysically but on the other hand her brother Bakha blames Sohini for her enchanting beauty. Bakha can't tolerate the sexual violation, which is done by Sohini's husband. He becomes impatience and restless.

\section{WOMEN ARE TAKEN AS PERSONAL POSSESSION, DEVOID OF ALL RIGHTS}

A woman is always considered a possession and personal property of the family of a husband for it is going on for a long time back, the apostolic days. The women are taken as physical body, who are supposed to seek pleasure and to dominate them with manly strength and power. And men finalize rules for them to follow and if the females don't follow them, they are tortured.A woman, who gives birth to a man, she is suppressed by him. It is really an irony of woman's life. In the Indian society it is not accepted that female should not think anything related to their life. Even they are not having right to decide anything for their future, only males are having all sorts of rights and they can use in any way. The female virginity is the prominent feature in the Indian society. The women, who are sexually pious, is admired and appreciated while those, who live in shame, lost the purity, are condemned and criticized.

Actually the women live in the oppression of the males deliberately and prepare $t$ themselves to perform varied roles duties and performances. The women forget about their real self or identity in process of giving their contribution as a daughter, wife and a mother under the control and surveillance of males. The veil system sympolizes the purity and chastity of women, it also reflects their pious character and dignified image in the society. The character BabuNathoo Ram wishes to treat as a genuine sahib but he keeps his own wife in double veil. He clarifies his practice by stating that she adopted it as voluntarily. And he frames her character and image as introvert, coy and a shy lady.

The women are just a puppet in the hands of the males; the body of the females is centralized meticulously in the apostolic society, where rules are just made only for women. The veil system is pressurized powerfully in the name of to intact the purity and piousness of women for it is perceived a worst sin to loss the purity. Actually in some cases, it is seen that veil system inbuilt pleasing and healthy relationship between the partners as it has taken place in the case of the two Rukmini and her fiancé. She herself realized that she is creating a barrier between them by drawing the veil in the presence of person, with whom she is going get married in near future.

The female body is over stressed; their body is taken as the source of enjoyment and entertainment only. Howsoever, they are talented and skilled that is always ignored. The women are most beautiful creation of god like her body. The sole purpose of veil system is to keep the young females invisible and unseen from the frictional sight of the dominant males.Since the birth of girl, she is taught to remain within her limits, she is not having any right even to keep herself happy in this men's world. She is alsoconvinced that she should obedient and adopt herself from the beginning; a concerted attempt is being made to make a woman realize her code of conduct of males. It is informed to the girl in a very tender age that she is not the permanent member of the family. She is just a burden for them. The entire family members frame the same negative image about the girl. And they also taunt for her every single mistake that she should everything perfectly otherwise wherever she will go after marriage, she will bring defames and disrespect to the family.

\section{IMAGE OF WOMEN IN PATRIARCHAL SOCIETY}

In the renowned work of Anand Untouchable, he has presented Bakha's character in the same frame; even he is not the least different in this reference. He structuralizes his mind that the body of his sister is a great threat and commination to the esteem and respect of his family.

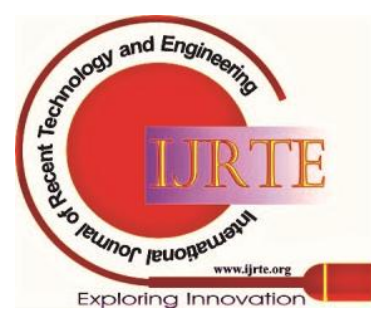


And he regards her as a burden to put her physic away from the evil sight of the males.He shouts in a great anger at her that she has taken birth to bring disrespect to the family. The male character, Pundit Kali Nath saves himself very clearly, inspite of his guilt of molesting Sohini. On the other hand Sohini, she is not having any fault of her own even then her brother Bakhaput all the responsibility of destruction on her. The women are required to remain under the strong surveillance of males in the society while the males are free to do anything. They are not having self-control over their physical desires.

Anand's next creation The Road, describes about the female character of Rukmini, whose mother puts several restrictions and hindrances on her own real daughter. She is suggested not state the names of young beings of this village. Even she is not allowed clad in bright and colorful attires. She has to wait to wear them till her marriage. On the other hand Bhikuhold an image of Rukmini but as he belongs to the untouchable family, so he is not having any future withher. Her brother, Sanju is free from all these restrictions. The boys are supposed to be mischievous, quarrelsome, and free to do height of worst while girls are needed to be clam, disciplined, obedient and should cultivate the habit of tolerating all sort of misbehave of anyone.In the novelUntouchable, again it shown that how the females are tortured in the Indian society. Sohini is not allowed giggle in the presence ofmales. And if the females are not following this code of conduct, finalized for them, they are made understand that this type of behavior suits only to the prostitutes. Therefore, the girls transform gradually into passive ones and the boys active and self-confident in the fields.

\section{CASTE AND WOMEN}

The girls, who are from the lower class, their parents get their marriage at very early age. As it is visible in the novel Untouchable, the sister of Ram Charan is wedded at very young age of only fourteen. When she is not aware about her own self and even her body organs are not fully developed. But the cruel society doesn't show any sympathy towards her. There is another character in the same novel, Sudhir Kakar, who gives illogical reasons of child-marriage practices.In fact the tradition of early marriage identified and it is framed in such a way to name it as it is a source of guarding the purity of young girl. When the girls play and develop physically and mentally at that very age, they are tied in the chain of marriage to get physically and mentallytortured by the worn and torn norms of the Hindu society. In Hindu class the women's marriage is supposed to be their fate and they give their entire life to this without thinking about themselves. The girls are taught to be obedient, kind, soft-hearted and tolerant since their childhood for they are going to be the housewife and they have make their dreams true by obeying her husband. In the novel, The Road, Rukmini, also thinks a better life after marriage.

As it is stated by Jyoti Puri, that wedding and becoming a mother, these two activities bring status in the society. These two are the rights as well as responsibilities of the women.The parents of girl starts searching a groom for their daughter, and with this procedure, the girl also finds that she is a responsibility to her parents. She also takes herself a guest or different member in her own family. When she looks at their parents getting disturbed for the financial problem, she holds herself responsible for all this and also thinks that she is a burden on her parents.

In the novel The Road, The characterBhagwanti, who is a father of a girl, makes her daughter understand that she is mere a guest in the house, and she will be married as soon as possible. Actually the father of Rukmini understands that his daughter can't help him at his old age. So he thinks her as valueless. Sometimes, the marriage of a lower- class girl brings good future for her parents. And they lead an affluent and comfortable life. The daughter of Gulabo is married and in exchange of that she receives two hundred rupees from the side of a groom. Therefore the daughter of Gulabo becomes a gift in place of a burden, who bring riches to her husband. The girl, who gets married, puts her respect and dreams at a stake, and lives for the wishes of others. She performs all the activities as they are chalked out in the patriarchal society. The doctrine of thepativrata revolves around her that is the central feature of her life. The prominent function of a pativrata is to keep the family line in progression by giving heir to the family. This is the most important function of a woman to get love, affection, honor and respect in the Indian society. A women's role as a wife is to preserve the social norms and to bring eternal life the men by giving birth to sons. The children performs all types of religious rituals, faithful service as well as bliss of God for the forefathers and for oneself depend totally on the wife. It is the misfortune of the aunty of Munoo, in the novel Coolie, unable to beget children for her husband and thus her respect and honor is lost in the society. These all things are coming from the patriarchal society, for here the womanhood is not fetching identity to her but it is motherhood, which fetch identity to the woman.

The concept of pativrata, a wifeneeds to be completely dedicated and obedient towards all the wishes and aspiration of the husband. If she denies or shows disobedience even for a single order, she is declared as a convict and becomes the opposite of pativrata. In the novel The Road, the character of Thakur Singh, shows this conventional ideology. He accepts that the females are not having right to speak before her husband, this type of bitterness is profoundly rooted within him. Even his wife if not has courage to speak anything before him. It is the perception of the Indian society that the females are made to maintain the household affairs. They should keep themselves bust tirelessly in the household activities to make an ideal home. It is the work of the absolute women.

The novel, Coolie, mother ofMunoo, does all the drudgery of house for her family without complaining anything. But actually she dies a slow death on the other hand in the novel Road;Rukmini realizes that it is highly boring to tie the women in the chain of domestic slavery. A woman 'soul is domesticated in home, where she losses herself in the drudgery of household activities

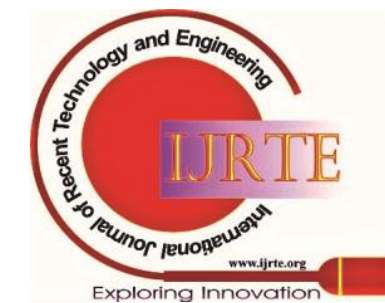


A woman is not having any free time for herself, for she maintains each and everything, related to the household activities tirelessly. In the novel, Untouchable,Bakha, recalls his mother with utmost affection and respect that she is totally suitable for the role of liberality, and deity of offering, always offering lady. All types of sacrifices of a woman make her an ideal one in the Indian society. But it does not allow her to live her life dependently and on her own norms.

Anand also tries to discover varied aspects of caste preconception that functions quite contrary to the interests of the females. As it is stated by Andre Beteille, that the word English 'caste' denotes to a supreme replica, a scheme or an outline of society, on the other hand jati denotes towards the actual social community by which the certain community of the people identify themselves and they interact to one another, keeping that an idea in their minds. In addition, caste is profoundly connected with several customs practices as well as with spiritual beliefs about a person's station in life.

The Brahmins are supposed to hold the top with their procedure pious selves as well as impiousness untouchables anguish at the bottom in a caste-ranking society. The First ranking caste enjoy social power with the complete hold over material resources by their ancestral background as well as with their contacts to the higher ranking people, in this process the females are the worst sufferers.

In the works of Anand, he shows the procedure and the spiritual base of caste in the Indian society.In the novel, The Road, the preconception of caste of the 'twice-born' Hindus shuts the doors of the templeforLaxmi. The inherent caste of laxmi, brings subjection to her as a chamar and later it leads to her suppression. In thenovel, Untouchable, the shrewd Brahmins molest the low-caste women whenever they get a chance.The shape of Rukmini's figure' attracts the attention of the priest, Suraj Mani, who belongs to the same the village.Even this does not bring repent for himself; he becomes irritated, when he fails to practice the rituals of Hindu in appropriate way. In the novel, Coolie, a bulgy saint lector the mantle of God himself, he is responsible to impregnate the wives ofthe merchant class for the birth of 'sons of God'. On the other hand, In Untouchable in captures the another incident, when Pundit Kali Nath tries to establish physical relation with an untouchable girl and when he fails and the people come he accuses her to impure the premises of the temple.

The idea of impurity follows the complex ideology of the patriarchical society, in relation of caste to keep the lowcaste people under suppression and put them under control, especially females.And they are the greatest sufferer in this regard for they are taken as weak figure of the society so they are suppressed and oppressed by the males, powerful section of the society.

\section{CONCLUSION}

It is a men's world so the males are following the ancient, conservative, worn and torn ideology of their forefathersin the Indian society, They think that if they have suppressed and tortured the ladies so we should also do the same. It doesn't matter if they are skilled and highly educated. It makes no difference on the treatment of the males to women; the males are having only one thought that the ladies are weaker section of the society so they should be kept under control, as their personal property, slave and a puppet, they should be taught dos and don'ts oftheir activities, without providing them freedom to think freely or to take decision about themselves and their children.

As it is reflected mostly in all the works of Anand that the females are the great sufferers, and they have suffered a lot for after marriage if the husband does not treat his wife well even the parents of a girl doesn't support her. They get rid of her, saying that now she is married and she has to adjust, only the house of a husband is the shelter place for a girl.

\section{REFERENCES}

1. Guha Ranajit (Ed.), Subaltern Studies, Vol.1, India, OUP, 1982, p.vii.

2. Anand Mulk Raj and HuthessingKrishna,The Bride's Book of Beauty,Bombay,Kutub Publication,1946,p.16.

3. Anand Mulk Raj,The Road, Bombay,Kutub Publication,1961,p.79.

4. Anand Mulk Raj,Untouchable, Arnold Associates, New Delhi, 1935,p.74.

5. Ashcroft Bill et al.Postcolonial Studies: The key Concepts, London, Routledge, 2007,p. 207.

6. KakarSudhir,Feminine Identity in India,inGhadially Rehana(ed),Women in Indian Society, New York, Sage Publication,1988,p.52.

7. Anand Mulk Raj,The Road, Bombay,Kutub Publication,1961,p.87.

8. Beteille Andre, Caste in Routledge Encyclopedia of Social and Cultural Anthropology,(ed) Alan Bernard and Jonathan Spencer,London, Routledge,2009,p.112.

9. Anand Mulk Raj, Apology For Heroism, Bombay,Kutub Publication,1946,p.81.

\section{BIBLIOGRAPHY}

1. Anand Mulk Raj,Untouchable, Arnold Associates, New Delhi, 1935.

2. Anand Mulk Raj and HuthessingKrishna,The Bride's Book of Beauty,Bombay,KutubPublication, 1946.

3. Anand Mulk Raj,Apology for Heroism, Bombay,Kutub Publication, 1946.

4. Ashcroft Bill et al.Postcolonial Studies: The key Concepts, London, Routledge, 2007.

5. Chakravarty Uma, Gendering India, Through a Feminist Lens, Calcutta, Stree, 2009.

6. Ghadially Rehana(ed), Women in Indian Society, New York, Sage Publication, 1988

7. Gramsci Anton, Selections from Prison Notebooks (Trans), Quentin Hoare and Geoffrey NewellSmith, London, Lawrence and Wishart,1971.

8. McDowell Linda, Gender, Identity and Place: Understanding Feminist Geographies, Cambridge,Polity Press, 1999.

9. Omvedt Gail (Ed.) Land caste and Politics in Indian states, Delhi, Authors Guild Publishers, 1982 .

10. Said Edward, Representation of the Intellectual, Knopf Doubleday Publishing Group, USA, 2012.

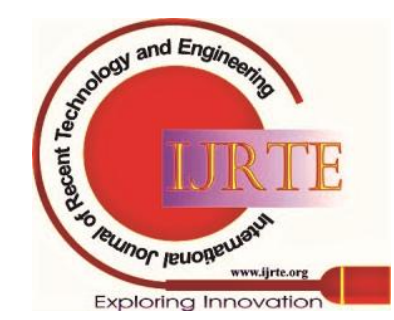

